\title{
Ballast Water Pollution in Saudi Arabia Ports
}

\author{
Mohamed Abbas Kotb ${ }^{\dagger \#}$, Amr Ali Hassan ${ }^{\dagger}$ and Hamad Hussain Ghurab ${ }^{\ddagger}$ \\ ${ }^{\dagger}$ Arab Academy for Science, Technology and Maritime Transport (AASTMT), on leave of Faculty of Engineering \#Alexandria University Marine \\ Engineering Department, Alexandria Egypt \\ ${ }^{\ddagger}$ Marine Engineering Ministry of Transport, Transports and Navigation Marine Department, Jeddah Saudi Arabia \\ Accepted 28 Nov 2015, Available online 16 Dec 2015, Vol.3 (Nov/Dec 2015 issue)
}

\begin{abstract}
The purpose of this research is to help the authorities concerned in the ballast water department of the KSA to assess and measure the negative effects resulting from the accidental entry of the invading microorganism into the KSA marine environment which will help to take the necessary decisions to reduce the risks and impacts resulting from the invading microorganism entering into the KSA coasts and beaches. The data this research has been collected so as to define the most contaminated ports in the KSA with the invading microorganism as a part of the ballast water management process in the KSA. The results of the present analysis indicated that, the Jeddah Islamic port at the Red Sea and the King Abdul-Aziz port in Dammam at the Arabian Gulf are the most affected ports by the entry of the invading microorganism. The ballast water treatment methods have also been clarified so as to be used in the ballast water management system and to reduce the entry of the invading microorganism into the KSA ports.
\end{abstract}

Keywords: Ballast Water Pollution etc.

\section{Abbreviations}

B.W.M Ballast Waters Management

B.W.I Ballast Waters Isolation

B.W.T.S Ballast Waters Treatment System

K.S.A Kingdom Saudi Arabian

M.B.W.C Methods Ballast Water Control

R.W.B Replace Water Ballast

\section{Introduction}

The maritime trade is considered as the backbone of the world economy because transportation of goods by sea is the most economical means, it transports huge and diverse quantities of goods to long distances around the world. The International Maritime Organization (IMO) statistics indicate that, the maritime trade represents about $90 \%$ of the international trade, the economic statistics indicate that, there are more than 36000 commercial ships navigating around the world with loads estimated to weight more than 300 million ton.[Ref. 1]

\section{The Negative Effects of the Ballast Water Problem}

The following paragraphs give an overview of the negative effects caused by the aquatic transmitted inside the ballast water tanks which affect the (environment, economy and human health).

\subsection{The Negative Effects on the Environment}

Every marine environment has physical and biological properties which define the power of this environment and its resistance to the dangers encountered as a result of the transmitting strange aquatic.

Most of the discovered environmental damages are beyond repair and considered as the most dangerous. The navigable Coasts, inland waters and estuaries are considered to be the worst affected because of the invading neighborhoods due to the weakness of the biological properties of these environments.[ Ref. 2]

\subsection{The Negative Effects on the Economy}

Displacement of indigenous fisheries by the invading kinds which reduces production of fish stocks and seafood.

The loss in fisheries productivity leads to the destruction of its facilities by the invading kinds which cause closure of the fish farms, and visible pollution such as algae and also causes disease to the farmed fish such as the white spot disease in the shrimp as shown below in Figure (1). 


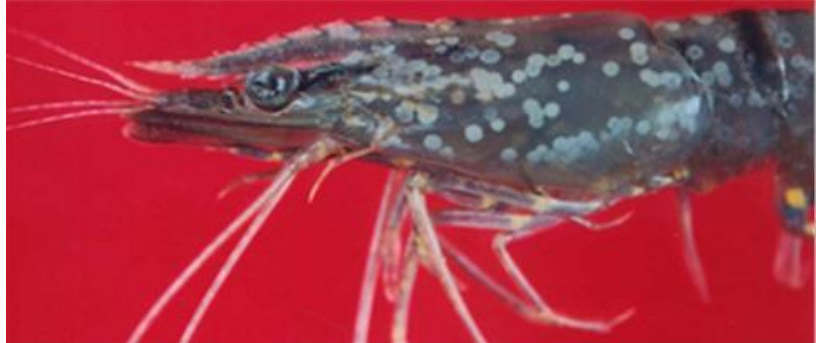

Figure 1: The White Spot Disease in the Shrimp Tiger Shrimp Ref.

[http://panchu.tripod.com/shrimp/disease/wssv_overview.htm]

The invading kinds cause big damages in the infrastructure such as port installations, docks, berths and touristic facilities, factories and power generating and desalination plants.

The high cost of avoiding or reducing the problems resulting from the invading kinds is represented in costs of researches, qualification, training on fighting pollution resulting from invading neighborhoods coming from ballast water tanks.[Ref. 3]

\subsection{The Negative Effects on Human Health}

The hybrid neighborhoods of unknown genes produce poisonous neighborhoods cause dangerous diseases if used as food for human being.

The invading kinds produce polluted environment help to spread diseases affect human being through direct contact in the costal or touristic areas.

There are studies that confirm the possibility of the return of cholera disease which is considered the most dangerous epidemics through the invading kinds where cholera lives in some kinds of algae transmitted in the ballast waters, these Algae's can pollute shellfish which is taken by human being as food.[Ref. 4]

\section{Study of Saudi Arabia Ports}

The KSA is situated at the South West Asia, overlooking the Red Sea and the Gulf of Aden and the Gulf of Aqaba from the Western side and the Arabian Gulf from the Eastern side.

There are seven ports scattered along the Red Sea and the Arabian Gulf as shown in Tables (1) and (2) The Tables show the numbers of ships for the past five previous years and the total incoming and outgoing for each port. [ Ref. 5]

Table 1: The Saudi ports along the Red Sea.[ Ref. 5]

\begin{tabular}{|c|c|c|c|c|c|c|c|}
\hline \multirow{2}{*}{} & \multirow{2}{*}{ Port Name } & \multicolumn{5}{|c|}{ Numbers of Ships for the Years } & Total of Import \\
Export / Ton
\end{tabular}

Table 2: The Saudi Ports along the Arabian Gulf.[ Ref. 5]

\begin{tabular}{|c|c|c|c|c|c|c|c|}
\hline & \multirow{2}{*}{ Port Name } & \multicolumn{5}{|c|}{ Numbers of Ships for the Years } & \multirow{2}{*}{$\begin{array}{l}\text { Total of Import } \\
\text { Export / Ton }\end{array}$} \\
\hline & & 2010 & 2011 & 2012 & 2013 & 2014 & \\
\hline 1 & $\begin{array}{c}\text { King A. Aziz Dammam } \\
\text { Port }\end{array}$ & 2243 & 2240 & 1894 & 1898 & 2064 & $\begin{array}{c}136.7 \text { million } \\
\text { ton }\end{array}$ \\
\hline 2 & RAS Al Khair Port & 0 & 60 & 173 & 156 & 157 & 11 million ton \\
\hline 3 & Jubail Commercial Port & 365 & 520 & 540 & 907 & 1038 & 34.9 million ton \\
\hline 4 & Jubail Industrial Port & 1654 & 1611 & 1606 & 1470 & 1800 & $\begin{array}{c}240.4 \text { million } \\
\text { ton }\end{array}$ \\
\hline
\end{tabular}




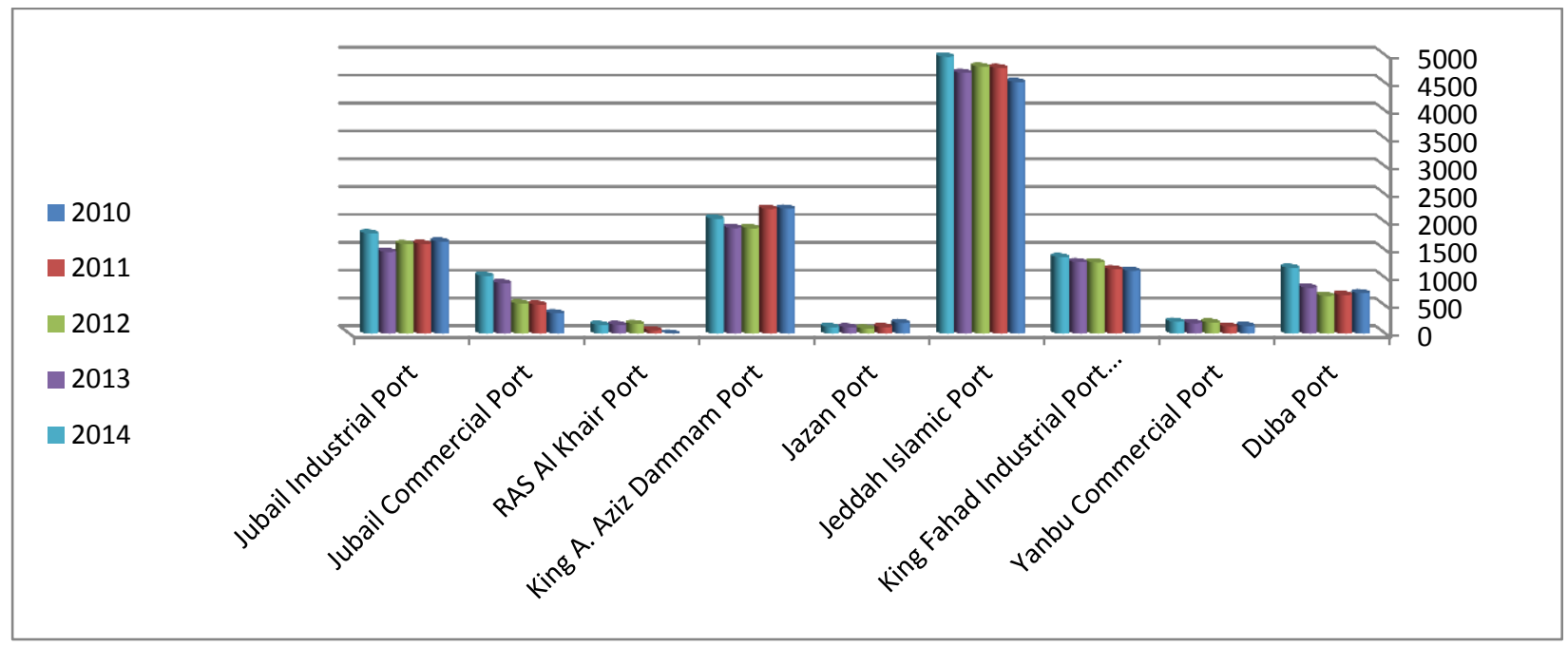

Figure 2: Comparison between ports of Saudi Arabia

Result is

- Statistically it turns out that the total exports and imports in Jeddah Islamic Port reached 280 million tons from 2010 to 2014 (in five years) at an average annual (4748 ships).

By calculation

(2010-2011) years: AVG $=(4519+4770) / 2=4645$

$$
\%=[(4770-4519) / 4519] * 100=5.6 \%
$$

(2010-2014) years: $A V G=(4519+4770+4793+4682+$ 4974) $/ 5=4748$

$$
\%=[(4974-4519) / 4519] * 100=10.1 \%
$$

- Statistically it turns out that the total exports and imports in Jubail Industrial Port reached 240 million tons from 2010 to 2014 (in five years) at an average annual (1628 ships).
By calculation

(2010-2011) years: AVG $=(1654+1611) / 2=1632.5$

$$
\%=[(1654-1611) / 1654] * 100=2.6 \%
$$

$(2010-2014)$ years: $A V G=(1654+1611+1606+1470+$ 1800) $/ 5=1628.2$

$$
\%=[(1800-1654) / 1654] * 100=8.83 \%
$$

Figure 3 shows comparison between Jeddah Islamic Port and Jubail Industrial Port.

Conclusion, increase rate of ships to and from Jeddah Islamic Port and Jubail Industrial Port, result to increase the proportion of pollution.

Which include these high ratio several sources of pollution Jeddah Islamic Port and the industrial port of Jubail as follows:

1) Oil pollution.

2) Pollution by sewage.

3) Waste pollution.

4) Ballast water pollution.

5) Chemical pollution.

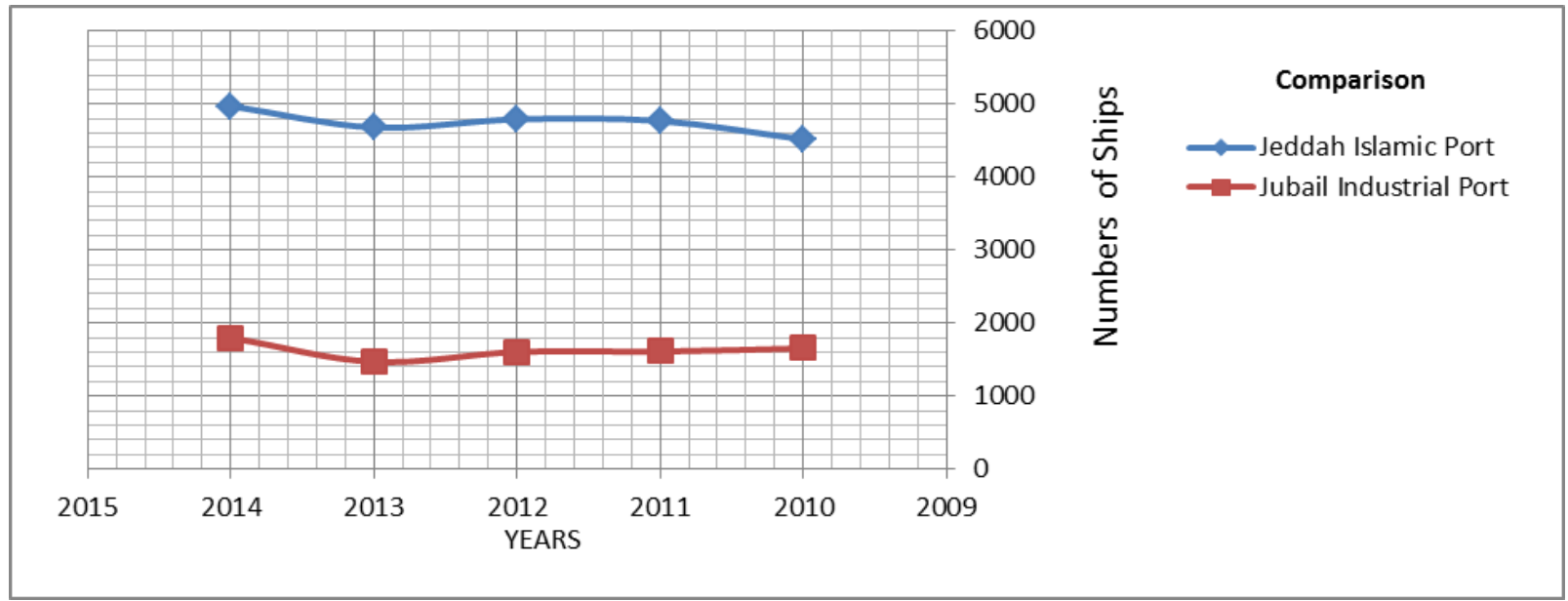

Figure 3: Comparison between Jeddah Islamic Port and Jubail Industrial Port 


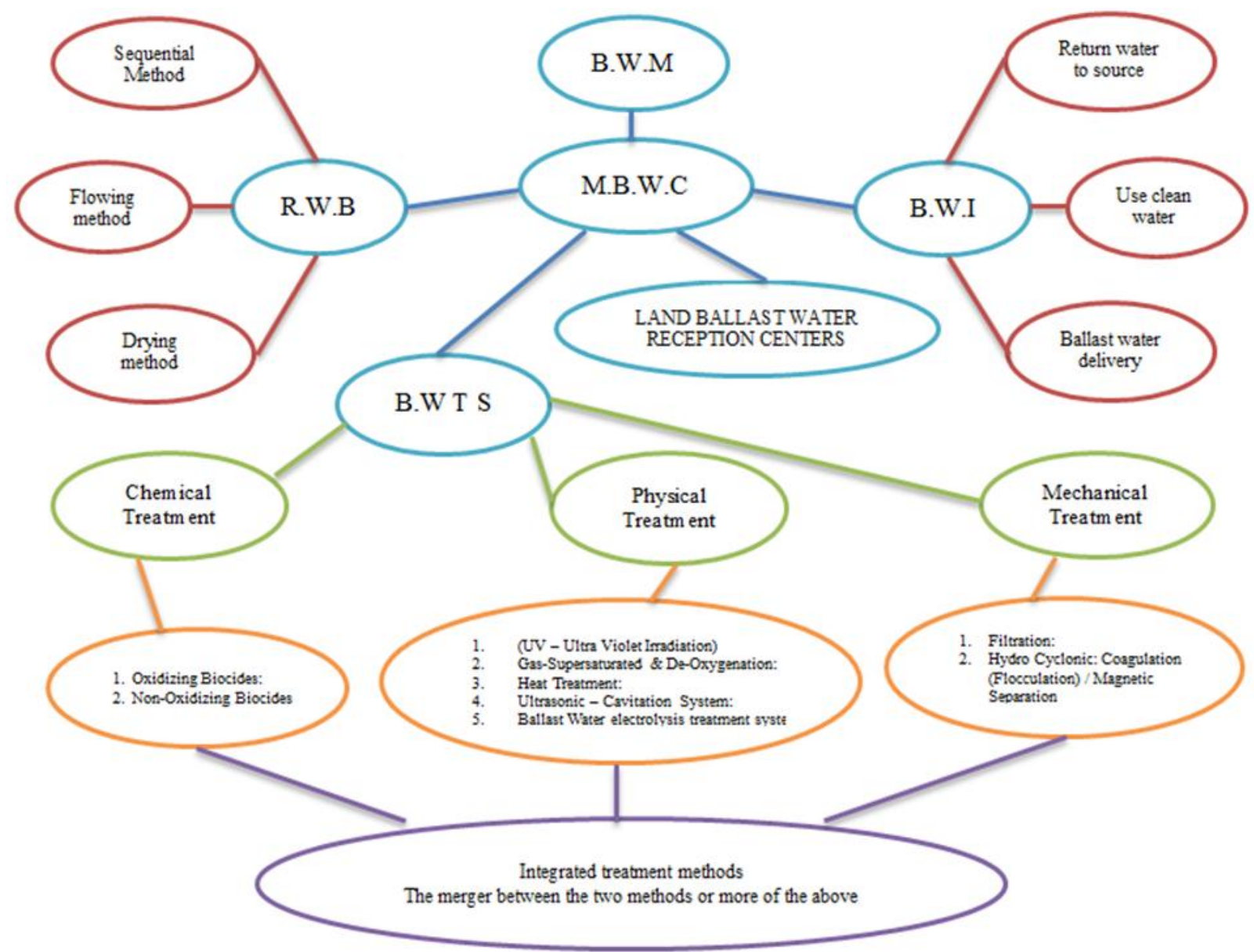

Figure 4: Methods of Ballast Water Treatment for Ships.Ref. Student

\section{Ballast Waters Management and Treatment Systems}

There water ballast management systems in use, as follows:

- Replace water ballast.

- Ballast waters isolation.

- Treatment systems for ballast water, divided into:

1) Mechanical treatment systems.

2) Physical treatment systems.

3) Chemical treatment systems.

- Land ballast water reception centers.

These solutions proposal can be applied to older vessels operating in the sea flying the Saudi flag. Figure 4 shows different water treatment methods

\section{The Results}

1) The invading organism transported by the ballast water causes environmental threat in general according to the classification of the (IMO).

2) The ballast water and sediments problem has no final solution because it is increasing for the reason that ballast water is considered of the ships operation basis.

3) It is necessary to develop protective measures to prevent any environmental damages resulting from ballast water because if the problem occurs it will be impossible to solve it.

4) Having several ports in the Saudi Arabia of high exporting capacity will make Saudi Arabia more vulnerable than others to the risk of exposure to the invading organisms.

\section{The Recommendations}

1) It is necessary increase the detailed environmental researches for each marine area to assess the pollution level in every area and to locate the affected and dangerous areas and also to locate the areas the most susceptible to contamination.

2) It is also necessary to develop ballast water treatments systems for high efficiency.

3) International and Education Agencies should develop qualifying and training curriculums for the personnel working in marine fields and how to use the ballast water management systems.

4) Cooperation between all countries is needed to put the international convention for the ballast water and sediment management into effect as fast as possible for its importance.

5) Reconsideration of some legislations in the Saudi Arabia to legalize and activate the ballast water and 
sediment management so as to be in conformity with the International standard.

6) Steps and actions must be taken to enable the Saudi Arabia to join the International Convention for ballast water and sediment management.

7) Activation of marine pollution in Saudi Arabia manage to put the emergency plan to protect the marine environment the risk of pollution and effects.

\section{References}

[1]. UNCTAD, (2008), "Review of Maritime transport, UNCTAD Report, 181PP.
[2]. J.Tame Lander, et al, (2010), "GloBallast monograph series No.18: Guidelines For development of a national ballast water management strategy", IMO, GEF, IUNC, GloBallast partnership project coordination unit, ISSN 1680-3078, London.UK.

[3]. IMO-Ballast water problem (2013), available online from: http:// globallast.imo.org/ problem.htm [July 2013]

[4]. Ruiz, et al, (2000), "Global spread of micro organisms by ships Ballast water discharged from vessels harbours a cocktail of potential pathogens", Nature, Vol. 408, 49-50.

[5]. Saudi Ports Authority- Media Center- Statistics, available online from: http://www. ports.gov.sa/english /statistics pages/ default.aspx . 